\title{
Swahili Literature
}

Tre Inter-territorial Committee suffered handicaps during the year I944 (the report on which only reached us in January) but the steady flow of manuscripts kept both staff in the office and readers in the territories constantly busy. Ten new works in Swahili were published; the manuscripts of nineteen others were under examination; fourteen other translations were made by the secretariat staff. Interest in the Swahili Essay and Authorship competitions was well maintained. One hundred and five entered the Essay competition. The subjects for the 'set essay' were : African Medical Treatment; Advantages and disadvantages of the Cinema to Africans. 'The committee regrets to note an indication of a certain element of contempt towards all things native and a complete reliance on European remedies and methods. In the opinion of the committee it is considered a pity, as indicating a certain superiority of attitude on the part of those still so much in the process of being " educated".' Only one essay was received from a pupil in a European school. Of the s9 'free essays' received in Tanganyika 39 consisted of traditional stories. Fifteen manuscripts competed for the Authorship Prize, which was awarded to a student of Makerere College. Of the total number eight were considered to be of considerable merit. "The Swahili used'-so say the adjudicators-' is generally very good but not in that elegant and finished style which should characterize works submitted for an authorship competition and which should be appealing to a good reading public.' But they are of the opinion that the works submitted give further evidence of awakening consciousness in the mind of the African to the deeper and more pressing views of life and the contribution he may make in the new day that has dawned for his country.

\section{The London School of Oriental and African Studies}

THe School is to be congratulated upon a very successful year of work, in spite of war conditions. We say ' in spite of' but as a matter of fact the war brought the School new opportunities and fresh successes: during the session (1944-5) ,67 students were enrolled from the three Fighting Services for the study of Japanese and other languages; and cxaminations for Prisoners of War abroad were conducted. From January 1941 to September $1945,32,312$ letters in 192 languages were read for the official British Censorship. In the Africa Department more students were enrolled than at any previous time. They numbered 82 in all; and 20 languages were taught-2I students took Yoruba and 14 Swahili. It is encouraging to notice that of the total number of students in the School, viz. 886, 104 were missionaries; but it is not so pleasing to see that only 12 were for full time; 30 entered for part time and 62 were 'occasional students'. No doubt the transport difficulties had something to do with this unsatisfactory state of affairs. As the Report says: "These short courses are not very productive, either for the students or the staff, and it is hoped that Missionary Societies will be able to arrange for longer periods of language study to fit in with the University sessions.' 'The strain on the staff can be imagined when it is called upon to teach a language to only one student for a single term. For the first time in the history of the School-or, indeed, in the history of any University-Africans came to London to study their own languages. Under the Colonial Development and Welfare Act studentships have been awarded to I Zanzibari, 3 Yoruba (one a woman), 2 Igbo and 2 Ashanti students to undergo training in general linguistics with special reference to their own languages. One of the main aims of the course is to train them for the work of directing the production of vernacular literature for school and mass education. The students are all teachers, some with many years' experience behind them. 'They have studied under the guidance of a specialist in each language and have attended lectures on Social Anthropology, the Principles of Translation, Methods of Language Study and Teaching, Bantu Grammar, \&c. 